\title{
REVIEW ARTICLE: THINKING AND WRITING ABOUT MEECH LAKE
}

\section{ALLAN TUPPER*}

In this article the author analyzes the writings on the Meech Lake Accord, concentrating on articles found in four major works on the topic. $\mathrm{He}$ concludes that Canadians were not well served by their academic community throughout the debate. It allowed the various governments and media to dominate the debate while ignoring key questions such as, "did the Accord reflect the priorities of contemporary Canadians?" This abdication in favour of the media is partially responsible for the country's current confusion about its future. He urges scholars to learn from the Meech Lake experience and challenges them to take a leading role in evaluating and commenting upon future constitutional proposals.
Dans le présent article, l'auteur analyse les écrits traitant de l'accord du lac Meech et s' attache surtout aux articles contenus dans quatre ouvrages importants. II conclut que les Canadiens n'ont pas été bien servis par la communauté universitaire au fil des débats. Elle a permis aux divers gouvernements et aux médias de dominer la discussion tout en ignorant des questions clés - si l'accord reflétait les priorités des Canadiens d'aujourd' hui, par exemple. $C$ 'est en partie a cette abdication en faveur des médias que l'on doit la confusion actuelle du pays au sujet de son avenir. L'auteur exhorte les universitaires d tirer leçon de l'experience du lac Meech et d assumer un rôle de leadership dans l'évaluation et la discussion des futures propositions constitutionnelles.

\section{TABLE OF CONTENTS}

I. INTRODUCTION $\ldots \ldots \ldots \ldots \ldots \ldots \ldots \ldots \ldots \ldots \ldots \ldots, 311$

II. MEECH LAKE AND CANADIAN FEDERALISM $\ldots \ldots \ldots \ldots \ldots, 312$

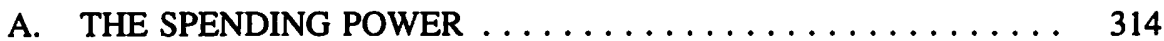

B. THE SUPREME COURT $\ldots \ldots \ldots \ldots \ldots \ldots \ldots \ldots \ldots \ldots \ldots$

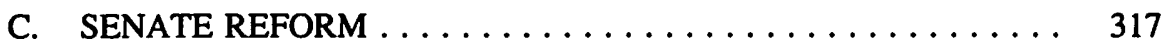

D. NEGLECTED ISSUES $\ldots \ldots \ldots \ldots \ldots \ldots \ldots \ldots \ldots \ldots$

III. THE PHILOSOPHICAL BASES OF

CONSTITUTIONAL REFORM $\ldots \ldots \ldots \ldots \ldots \ldots \ldots \ldots$

Department of Political Science at the University of Alberta. This review deals with articles from the following books:

COMPETING CONSTITUTIONAL VISIONS: THE MEECH LAKE ACCORD edited by K.E. Swinton and C.J. Rogerson (Agincourt, Ontario: The Carswell Co. Ltd., 1988), pp. xxii + 328.

THE MEECH LAKE ACCORD supplement (1988) XIV Canadian Public Policy, pp. S156.

MEECH LAKE AND CANADA: PERSPECTIVES FROM THE WEST edited by Roger Gibbins with Howard Palmer, Brian Rusted and David Taras (Edmonton: Academic Printing and Publishing, 1988), pp. $x+283$.

THE MEECH LAKE PRIMER: CONFLICTING VIEWS OF THE 1987 CONSTITUTIONAL ACCORD edited by Michael D. Behiels (Ottawa, Ontario: University of Ottawa Press, 1989), pp. xxiv +564 . 
IV. THE PROCESS OF CONSTITUTIONAL REFORM $\ldots \ldots \ldots \ldots \ldots 326$

V. THE POLITICS OF CONSTITUTIONAL REFORM $\ldots \ldots \ldots \ldots \ldots 330$

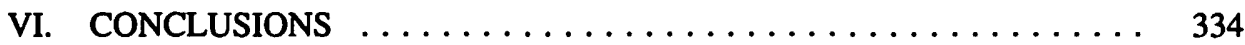

\section{INTRODUCTION}

For three difficult years, the contents of the Meech Lake Accord evoked intense debate among concerned Canadians. And regardless of the Accord's demise in June 1990, the controversy surrounding it will determine in profound ways the future course of Canadian constitutional development. My objective in this essay is to review the more important collections of English Canadian scholarly essays about the Accord. Among other things, I try to highlight some of the more illuminating contributions, to give an overview of the range of scholarly concerns about the Accord and to pose some questions that merit further attention and research. My premise is that before again embarking on constitutional discussions we must reflect deeply on the tumultuous Meech Lake experience. For each round of constitutional debate directly and indirectly structures future negotiations, sets new priorities and discards old ones, and creates new attitudes while reinforcing existing ones. We must therefore understand our immediate past before embracing hastily conceived blueprints for the future.

Like most observers, I argue that the post-Meech agenda will be considerably more complex than the present one and that Canadian scholars must exhibit greater creativity, sophistication and objectivity if they are to contribute fully to the difficult debates of the 1990s. The Meech Lake debate has forced Canadians and possibly their governments to think deeply about a range of complex political questions. Scholars must also use the constitutional controversy as a basis for careful reflection about the adequacy and nature of their contributions, their frameworks for analysis and their conclusions.

As a political scientist, my remarks stress, but are by no means limited to, the contributions of my discipline. And to employ Alan C. Cairns' apt term, I write as an "outsider" to Canadian constitutional debates.' That is, I am neither an advisor to government or an interest group nor one of the rather small group of academics who have written extensively about Canadian constitutional affairs.

The scholarly literature on Meech Lake, some of it written quite soon after the Accord's public announcement, is generally competent and often stimulating. But my theme is that it is flawed in several important ways. First, several crucial components of the Accord, for example, the proposed changes to the constitutional order for immigration, received scant attention relative to other proposals. The Accord's possible implications for the substance of future governmental policy are seldom fleshed out in detail. Second, the literature is further flawed by its tendency to ignore the philosophical bases of

t. Alan C. Caims, "Ritual, Taboo and Bias in Constitutional Controversies in Canada, or Constitutional Talk Canadian Style" (1990) 54 Sask. Law Rev. 121. 
constitutional debate. More specifically, authors seldom outline explicitly either the philosophical premises of their arguments or clear criteria for the evaluation of constitutional revisions. As a result, readers are presented with impassioned arguments for or against the Accord without being given an explicit intellectual framework for resolving competing claims. The debate about the interplay between the Distinct Society clause and the Charter of Rights and Freedoms is made particularly complex and frustrating by a failure to address several deeper questions about our constitution, notably the political purposes and interests served by constitutions in liberal democracies. A third flaw is the scholarly community's failure to break away from the governmental debate about the Accord, to apply new lenses to our constitutional binoculars and to bring to bear creatively insights from our disciplines. The literature, with some noteworthy exceptions, followed the governmental agenda and debated the Accord on the same terms as governments. Basic questions about the distribution of political power and the relations between social classes in Canada were seldom probed. Finally, the literature provides few general interpretations of our recent constitutional experiences. Careful and considered essays were drafted on such topics as Meech Lake's impact on the Supreme Court, the Senate, the spending power and the Charter. Perceptive commentaries exist about the response of women, aboriginal peoples, and ethnic groups. And useful debates have occurred about the Accord's probable impact on the relative powers of the federal and provincial governments and the democratic quality of the processes employed. But few scholars have advanced wide-ranging or iconoclastic interpretations of the entire process with a view to linking the Meech Lake struggle with broader trends in contemporary Canadian politics or for that matter in the politics of other advanced democracies. Arguably, such assessments may proliferate after the dust settles but the extant literature provides little grounds for optimism.

I approach these questions by probing the literature in four areas - the Accord's allegedly decentralizing effects on Canadian federalism, the links between the Accord and the Charter, the process of constitutional change, and the underlying politics of Meech Lake. Since only a few issues are selected for intensive examination, my approach is admittedly selective. But the questions and themes selected for close scrutiny are both inherently important and at the centre of the broader debate about the Accord. They will undoubtedly resurface, possibly under different rubrics, in future constitutional discussions.

\section{MEECH LAKE AND CANADIAN FEDERALISM}

The Meech Lake proposals sparked a fiery debate about where power should lie in the Canadian federal state. Diverse critics were united by the view that the Accord, if passed, would have unduly enhanced the power, status and visibility of the provincial governments while restricting and denigrating Ottawa's capacity to speak for all Canadians and to embark on desirable national initiatives. A common view of critics was that changes necessary to secure Quebec's consent to the constitutional order were unwisely conferred on the other provincial governments so as to gain quickly their consent. The strongest champion of this viewpoint is Pierre Elliott Trudeau, whose powerful 
interventions early in the debate became the rallying point for opposition. To quote $\mathrm{Mr}$. Trudeau: ${ }^{2}$

Quebec's five demands were all met in ways which weakened the fabric of Canada by denying the existence of a national will over and above the will of the provinces. The 1987 accord brings us back to the "compact" theory of the 1927 conference, that Canada exists as a country not by the will of its people but by the leave of its provincial governments.

Those concerned with the decentralizing influence of Meech Lake painted a distressing picture of how the amending formula proposals with their enhanced emphasis on unanimity, provincial government involvement in the appointment of Supreme Court judges and Senators, and the provisions relating to the spending power and immigration would have combined to weaken Canada's already tenuous sense of national community. As A.W. Johnson argued, the cumulative impact of Meech Lake's proposals might have been a paralysed federal government especially in the welfare state sphere and weakened national institutions as over time they become populated by provincial spokespersons. ${ }^{3}$ David Bercuson, an historian and outspoken critic of the Accord, challenged Meech's view of the premiers as reasonable guardians of the public interest by raising the spectre of such rogues as Premiers Duplessis, Hepburn, and Aberhart. ${ }^{4}$ What havoc would such men have wreaked with the powers conferred on their governments by Meech Lake and how can we be confident that such reactionary leaders will not resurface?

Other critics of the Accord employed less hyperbole and more caution in their pronouncements. Roger Gibbins, for example, worried about whether the "provincializing" thrust of the Meech Lake Accord is congruent with the social and political realities of contemporary Canada. ${ }^{5}$ Moreover, like other critics he was concerned about the acute absence of any spirited defence of the national interest by Prime Minister Mulroney. Unlike the process culminating in the Constitution Act of 1982, the Meech Lake exercise was not characterized by a tension between competing federalist and provincialist views of a proper constitutional order. In 1987, the provincial view held sway unchecked by the countervailing vision of a determined national leader.

Meech Lake supporters advanced a radically different picture of the Accord's underlying rationale and its impact on intergovernmental relations. They stressed that Meech Lake embodied no significant alterations to the federal-provincial division of

2. Pierre Elliott Trudeau, "Who Speaks for Canada: Defining and Sustaining a National Vision" in Michael D. Behiels, ed., The Meech Lake Primer: Conflicting Visions of the 1987 Constitutional Accord (Ottawa, Ontario: University of Ottawa Press, 1989) 60 at 88.

3. A.W. Johnson, "The Meech Lake Accord and the Bonds of Nationhood" in K.E. Swinton and C.J. Rogerson, Competing Constitutional Visions: The Meech Lake Accord (Agincourt, Ontario: The Carswell Co. Ltd., 1988) at 145-53.

4. David Bercuson, "Meech Lake: The Peace of the Graveyard" in Roger Gibbins, ed., Meech Lake and Canada: Perspectives from the West (Edmonton: Academic Printing and Publishing, 1988) at 17-21.

5. Roger Gibbins, "A Sense of Unease: The Meech Lake Accord and Constitution-making in Canada" in Gibbins, ibid. at 121-129. 
powers. Ottawa's power to manage the economy, for example, was unfettered. But the supporters' defence was ultimately rooted in the view that Meech's provisions would have engendered more frequent and intense intergovernmental interaction and that such greater interdependence would have been benign. The spending power provisions and those relating to judicial and Senatorial appointments would have compelled governments, each armed with important influences over the outcome, to deal reasonably and directly with each other. As Peter Leslie, a political scientist and defender of the Accord, puts it: "The essence of the Meech Lake agreement is that almost all its clauses will intensify the processes of intergovernmental negotiation, mostly on a bilateral basis." ${ }^{\text {" }}$ For Meech Lake's protagonists, the more interdependent, cooperative federalism of the future represents a welcomed alternative to the conflict-ridden processes of the last two decades. Moreover, Meech's supporters saw no inevitable, irreversible trend toward a decisively decentralized federation. Power relationships within the federation, although structured in some areas by the Accord, would continue to be determined by many factors including domestic and international economic developments. Finally, defenders argued that provincial involvement in appointments to a crucial national institution like the Supreme Court was a desirable development, given the Court's considerable role in shaping intergovernmental relations.

\section{A. THE SPENDING POWER}

One of the more interesting aspects of the Meech Lake controversy surrounds the spending power. The debate about the spending power reflected the considerable diversity of scholarly opinion about the spending power specifically and the Accord generally. Meech's critics focused on the spending power provisions as evidence of the agreement's probably perverse impact on Ottawa's capacity to forge necessary social and economic policies in the future. They noted the indisputably imprecise language of section 106A and lamented that in the future an ill-equipped judiciary would have been called upon to resolve basic questions about the development of the Canadian welfare state. A deeper concern, however, was that under Meech Lake federal leadership would have been difficult and the "opting out" procedures would have permitted a maze of provincial programs embodying very different standards. In the worst case scenario, Meech Lake's spending power provisions, by demanding extensive intergovernmental negotiations on new shared cost programs, may have caused Ottawa to refrain from launching new initiatives. Deborah Coyne, a severe critic, summarizes her case in this way: ${ }^{7}$

The Meech Lake proposals will severely constrain the federal government's ability to initiate new programs and impose critical national standards in a variety of areas that may require national action in the future ..., we will end up with a patchwork quilt of national social and economic programs - a

6. Peter M. Leslie, "In Defence of the Spirit of Meech Lake: Evaluating the Criticisms" in Behiels, ed., supra, note 2, 483 at 503.

7. Deborah Coyne, "The Meech Lake Accord and the Spending Power Proposals: Fundamentally Flawed" in Behiels, ed., supra, note 2, 245 at 246. 
checkerboard Canada guided by cash register politics - something that will increasingly attenuate our sense of national community.

Counterpoised against such a view is the idea that the spending power proposals are not restrictive enough. This viewpoint was strenuously advanced by Andrew Petter, a constitutional lawyer, who denounced the spending power as incompatible with both federal and democratic principles. ${ }^{8}$ A related argument, set forth by André Lajoie, a law professor at the Université de Montréal, also saw the spending power provisions as too permissive and as threatening to provincial autonomy. ${ }^{9}$ Her paper should be carefully read as a reminder of the often considerable divergence of scholarly opinion between Quebec and English Canada about Meech Lake. For what is seen in English Canada as a threatening assauit on Ottawa's authority may be interpreted within Quebec as a considerable intrusion into provincial affairs.

The most convincing arguments lie between the extremes described above. Several authors portrayed section 106A as an effective intergovernmental compromise in the face of decades of controversy about the spending power. ${ }^{10}$ The spending power was recognized in the constitution but was made subject to certain limits. Moreover, the provisions apply only to new shared cost programs in areas of provincial jurisdiction thereby leaving untrammelled Ottawa's ability to transfer monies either directly to individuals or to provincial government institutions. Both the federal and provincial governments realized some of their objectives with the result that future bargaining about new programs would have been structured by the terms of section 106A. In a related vein, most commentators dismissed the argument that debates about the spending power, and by implication about the development of the welfare state, would have been transferred to the courts. Stefan Dupré, in aptly describing 106A as "a showcase of uncertainty," argued that governments will continue to resolve disputes about fiscal relations through the traditional route of political negotiations. ${ }^{11}$ Governments will prefer to operate in an admittedly ambiguous area rather than run the risk of a "winner take all" result through judicial intervention. A final, and perhaps compelling, argument was that the national shared cost programs that form the core of the Canadian welfare state and that are the subject of section 106A are unlikely to be prominent features of future intergovernmental agreements. The intergovernmental "action" will be in a number of grey constitutional areas including the environment and economic adjustment. In such policy areas, the program delivery mechanism will probably stress bilateral not national undertakings. Meech Lake's spending power provisions will not influence government's

8. Andrew Petter, "Much Ado About Nothing? Federalism, Democracy and the Spending Power" in Swinton and Rogerson, eds., supra, note 3 at 187-201.

9. Andrée Lajoie, "The Federal Spending Power and Meech Lake" in Swinton and Rogerson, eds., supra, note 3 at $175-185$.

10. See, for example, Pierre Fortin, "The Meech Lake Accord and the Federal Spending Power: A Good Maximin Solution" in Swinton and Rogerson, eds., supra, note 3 at 213-223.

11. J. Stefan Dupre, "Section 106A and Federal-Provincial Fiscal Relations" in Swinton and Rogerson, eds., supra, note 3, 203 at 208. 
capacities to respond in these new areas of intervention. Indeed, Tom Courchene, an expert on Canadian economic policy, saw Meech Lake as exerting a benign effect on Canada's capacity to respond to the challenges of a changing international order, an aging population, and complex domestic fiscal and economic problems. ${ }^{12}$

In a provocative assessment, Keith Banting forces readers to think beyond the intergovernmental agenda and to ponder the impact of section 106A on the future character of the welfare state in Canada. ${ }^{13}$ His assessment is that Meech Lake, with its overriding emphasis on intergovernmental collaboration and consensus, would have slowed the pace of social reform and made bold new interventions unlikely. Moreover, progressive policies in some provinces would have been offset by the stances of more conservative provincial administrations. As a result: "The social costs of such a change would be borne primarily by the poor and vulnerable in those provinces that chose to go less far than they would have done under stronger federal direction."14 Banting's argument is one of the few that urges readers to conceive Meech Lake, and by implication other constitutional changes, as undertakings that hold considerable importance for class relations, the distribution of income, and the content of public policy.

Underpinning Banting's arguments and the broader debate about the spending power are several perennial concerns of observers of Canadian politics including - which level of government is the likely source of progressive social policy and what institutional mechanisms are necessary to maximize progressive inclinations? Seen in this light, the Meech Lake controversy about the spending power is part of a larger, continuing struggle between those who see Ottawa as the primary vehicle of reform and those who see the provincial governments as innovators in social policy matters. Underpinned by clearly divergent perspectives, the debate about government's roles in social policy formation will continue in future constitutional and political debates especially if Ottawa's capacity to forge important national initiatives is thought to be in question.

\section{B. THE SUPREME COURT}

Discussion of Meech Lake's impact on the Supreme Court was neither wide-ranging nor intense with the bulk of commentary being supportive of the proposed changes. In a thoughtful essay, Peter Russell noted that Meech Lake represents a major advance in nation-building insofar as Quebec elites were willing to accept the Supreme Court as the final umpire, having abandoned past proposals for separate courts. ${ }^{\text {is }}$ The idea of Supreme Court judges being selected through lists provided by the provincial governments

12. T.J. Courchene, "Meech Lake and Socio-Economic Policy" (1988) XIV Canadian Public Policy at 63-80.

13. Keith Banting, "Federalism, Social Reform and the Spending Power" (1988) XIV Canadian Public Policy at 81-92.

14. Banting, ibid. at 90 .

15. Peter Russell, "The Supreme Court Proposals in the Meech Lake Accord" (1988) XIV Canadian Public Policy at 93-106. 
with the choice ultimately resting in federal hands was also regarded positively in most quarters. Provincial government involvement was generally seen as a step toward making the court a truly national institution. Peter McCormick, a political scientist, argued that the process would have engendered competition between provincial governments outside of Quebec with the result that only excellent candidates would have been advanced. ${ }^{16}$ The provinces realized that Ottawa would simply have gone to another province's list if mediocre candidates were advanced. The absence of a deadlock breaking mechanism was not seen as a serious problem. Nor was the proposal for unanimous intergovernmental approval of future changes to the Court regarded as a basic flaw. In contrast to the United States, where the executive does not control the legislature, executive dominance of the Canadian legislative process makes the hurdle of unanimity less daunting.

A disappointing aspect of the Supreme Court debate was the absence of widespread argument about the need to expand involvement in the selection process beyond governmental actors. The Canadian Association of Law Teachers' call for Judicial Nominating Councils is reprinted in one of the volumes but the merits of such a proposal and alternative designs for greater public input into the selection of judges are not the subjects of sustained analysis. ${ }^{17}$ Interestingly, a provincial role in judicial appointments was seen as a step toward greater democracy but the more obvious democratic case - for broader non-governmental involvement - was seldom made.

\section{SENATE REFORM}

Although Senate reform was defined as a crucial element of Alberta's constitutional design and of the western Canadian constitutional agenda, the issue is not dealt with at length in the literature. Two conflicting interpretations emerged. ${ }^{18}$ The first is pessimistic about Meech Lake's impact on the prospects for substantial Senate reform. This view lamented that the requirement for unanimous intergovernmental agreement made Senate reform, particularly of the "Triple E" variety, unlikely. The opposition of Ontario and Quebec was assumed to be a major roadblock. A related concern was that the interim reform proposed at Meech Lake - to allow provincial governments to nominate Senators subject to federal acceptance - might have become a permanent feature. The premiers would have come to appreciate both the patronage at their disposal and the capacity to use the Senate as a vehicle for obstructing federal policy-making. In the worst case scenario, the Meech Lake proposals might over the medium term lead to a powerful upper house packed with staunch provincialists and armed with its presently potent powers. A more optimistic view, ably advanced by Peter Meekison, argued that

16. Peter McCormick, "The Courts: Toward a Provincial Role in Judicial Appointments" in Gibbins, ed., supra, note 4, at $45-50$.

17. Canadian Association of Law Teachers, "Democratizing our Legal System: The Case for Judicial Nominating Councils" in Behiels, ed., supra, note 2, at 391-96.

18. For an overview see David Elton, "The Enigma of Meech Lake for Senate Reform" in Gibbins, ed., supra, note 4, at 23-32. 
Meech Lake advanced the cause of Senate reform. ${ }^{19}$ It linked the issue with future constitutional discussions by making it a subject for constitutional discussion until reform was achieved. Moreover, the new unanimity requirement was not the straitjacket that critics assume. Regardless of the amending formula, it is unlikely that major Senate reform would be undertaken in the face of determined opposition from Ontario or Quebec.

The literature and the broader debate about Meech Lake simply assumed that some sort of substantial Senate reform is both necessary and desirable. It therefore emphasized the question of whether Meech Lake enhanced or reduced the prospects for reform. Scant attention was paid to such important issues as the political and philosophical bases for Senate reform, the impact of various reform proposals on governmental accountability and policy making, the case for abolition or the impact of basic change on either federal-provincial relations or responsible government.

The frantic week long constitutional negotiations in Ottawa in early June 1990 highlighted our amateurish approach to Senate reform and indirectly revealed the deeper inadequacies of the Meech Lake process. Various Senate reform proposals were apparently bandied about the frenzied negotiations. But these were advanced in the absence of public discussion, clear rationales or a prior consensus about the need for Senate reform. And "Triple E" enthusiasts learned first hand that neither their grand design nor other alternatives had been seriously discussed in Quebec. Under these circumstances, the ill-fated companion document's commitment to study Senate reform for up to five years might have saved the country from a potentially serious constitutional error.

In summary, an assessment of the arguments about Meech Lake's impact on the Canadian federation leads to the conclusion that the views of the extreme opponents would not likely have been substantiated. Meech Lake's proposals would not by themselves have generated the balkanized, divided, possibly impotent, federal state envisioned by the most severe critics. On the other hand, critics, supporters and detached observers are unanimous in their view that Meech Lake's proposals would have enhanced the power, visibility and status of the provinces. They differ only about the desirability of Meech's "provincializing" effects.

While the views of the outspoken critics are exaggerated, the mainstream of English Canadian scholarly opinion is critical of Meech Lake's impact on federal-provincial relations. In a powerful assessment, Alan $\mathrm{C}$. Cairns neatly summarized several continuing concerns: ${ }^{20}$

In sum, the Meech Lake vision of federalism postulates more provincialized central government institutions, an enhanced provincial government role in an enlarged intergovernmental arena, and a federal

19. J. Peter Meekison, "Meech Lake and the Future of Senate Reform" in Swinton and Rogerson, eds., supra, note 3, at 113-120.

20. Alan C. Cairns, "Ottawa, the Provinces and Meech Lake" in Gibbins, eds., supra, note 4, 105 at 115. 
government which has voluntarily fettered much of the discretion it formerly enjoyed and wielded. This enhanced provincial role is not the product of a triumphant political theory which irresistibly champions this direction of change, nor of a sensitive judgement of the most appropriate structure of federalism to respond to the policy demands of the future. These possible rationales are conspicuously absent from the Meech Lake discussions.

In this vein, many observers note that such features of Meech Lake as a constitutionally recognized role for provincial governments in appointments to national institutions represented a striking departure from traditional Canadian theories of federalism. But only a few analysts, ironically the most noteworthy being Pierre Trudeau, tried to locate such changes in a coherent philosophical framework. What political and social values would Meech's "provincializing" initiatives have promoted? Whose interests might have been served by their acceptance? What virtues are implicit in the Meech Lake proposals as compared with the status quo or other reform models? What criteria should citizens employ as they wrestle with the task of establishing their positions on the Accord and future constitutional changes? Answers to these questions remain elusive after three years of debate. Governments, by anchoring their defence of Meech Lake in terms of national reconciliation, avoided deeper discussion of their proposals. Scholars, by failing to root their assessments in broader theories of federal systems and by examining the changes individually rather than as a whole, have done little to fill the void.

In post-Meech Lake Canada, questions about the political and economic effectiveness of federal structures, far from receding, will gain greater prominence. A range of reform proposals may well emerge from Quebec which challenge traditional assumptions about our political order. Such proposals will be enormously difficult to assess and will challenge the academic community's resources. If, like the Meech Lake proposals, future reforms are advanced by governments without clear rationales, social scientists must locate them in their broader political, economic and social contexts. We did not do so during the Meech Lake debate.

Immediately after Meech Lake's death, many observers called for a cooling off period wherein governments and citizens could calmly reflect on the events of the last three years. But Quebec has already announced its intention to engage in bilateral negotiations with the federal government with a view to striking new relationships in a series of policy areas including immigration and communications. Two key points arise about such negotiations. First, we are reminded forcefully that important alterations to the federal-provincial balance can be achieved without engaging in formal constitutional negotiations. Second, it is possible that the other provinces will demand either arrangements comparable to those negotiated between Ottawa and Quebec or some sort of as yet unspecified "new deal." Rather ironically, the decentralization so feared by Meech Lake's opponents might well occur, but incrementally and in the absence of an overarching public philosophy. 


\section{NEGLECTED ISSUES}

Narrow as it is, the literature about Meech Lake's impact on federalism almost completely ignored two questions - immigration policy and the impact of "constitutionalized" annual First Ministers conferences on the economy. Meech's provisions in both areas would have exerted significant effects on future intergovernmental relations. The neglect of immigration policy is particularly problematical given Quebec's intention to extend its sway over this policy area through a new bilateral accord with Ottawa.

Immigration policy, while a topic of considerable importance to interest groups and possibly the general public, spurred neither much analysis nor any penetrating debate among experts. Meech Lake's provisions on immigration are often mentioned in passing. The point was made that the Accord merely gives constitutional recognition to an existing Quebec-Ottawa administrative agreement while offering similar capacities to the other provinces. But in a penetrating critique, Orest Kruhlak wondered about the logic of major changes to the status quo, worried about the impact of the proposed changes on the substance of future immigration policy and raised the possibility of unanticipated problems in Ottawa's conduct of foreign policy. ${ }^{21}$ Whether completely founded or not, Kruhlak's concerns point to the acute and continuing lack of focused discussion of a matter of great political, economic and social significance.

The proposal for an annual First Ministers' conference on the economy was little analyzed. Perhaps this was so because such meetings are now such an ingrained part of Canadian political life that their further formalization seems of little consequence. In this context, Meech's proposals, far from representing a threatening departure, merely reflect an institutional recognition of government interdependence. But one wonders whether this perspective is accurate. As several economists contend, Meech Lake's proposals in this vein might have further politicized decision-making and thereby undercut the necessary interaction between experts that underpins economic policy-making. ${ }^{22}$ The relative neglect of this constitutional entrenchment of "executive federalism" is surprising in light of the considerable criticism, on grounds of democratic procedure, of the First Minister's dominance of the process culminating in the Accord.

Economists made few contributions to the debate about Meech Lake and we are probably worse off because of their abstinence. Without falling into the trap of generalizing about the perspectives of heterogeneous disciplines, it is probably fair to assert that most economists do not see constitutional provisions as having much impact on the substance of policy. As a result, assessments of constitutional change become the fiefdoms of constitutional lawyers and political scientists regardless of the limitations and biases of these disciplines. Given Meech Lake's failure, our next round of national

21. Orest Kruhlak, "Constitutional Reform and Immigration" in Gibbins, ed., supra, note 4, at 201-217.

22. Robin Boadway, Jack M. Mintz and Douglas D. Purvis, "The Economic Policy Implications of the Meech Lake Accord" in Swinton and Rogerson, eds., supra, note 3, at 225-235. 
discussions will explicitly examine more radical political and economic alignments including (once again) some form of sovereignty association. The expertise and perspectives of modern economics will be required in any such discussions.

The literature is virtually silent on how the Accord might have shaped the future content of Canadian public policies. As noted earlier, the debate stressed the question of the balance of federal and provincial power and the impact of proposed changes on, and to a lesser degree between, political institutions. In passing, supporters and critics alluded to policy areas that might have been influenced by Meech's provisions. No serious analyses are evident, however, of how Meech Lake might have structured policy making so as to favour certain outcomes and to work against others. Nor was much mention made of the possible winners and losers.

\section{THE PHILOSOPHICAL BASES OF CONSTITUTIONAL REFORM}

A major development in the recent literature on Canadian constitutional change is the emergence of a dominant interpretation. In a number of iconoclastic and wide-ranging essays, Alan C. Cairns argued that since 1982 Canadian constitutional politics have involved two competing perspectives. ${ }^{23}$ The first perspective, labelled by Cairns "the governments' constitution," emphasizes such perennial questions as the balance between federal and provincial powers, the amending formula, the status of Quebec and the relationships between French and English Canadians. This governmental agenda lies at the heart of the Meech Lake Accord. But often co-existing uneasily with this traditional agenda is the "citizens' constitution." Since the advent of the Charter of Rights and Freedoms in 1982, Canadian constitutional life has assumed new dimensions. The Charter shaped a new agenda focusing on individual and group rights, mobilized new groups and expanded significantly the range of Canadians who define constitutional matters as serious business. As Cairns argues: "The Charter redefined the citizenry as bearers of rights; it stressed the Canadian (not provincial) dimension of their identities; and it gave them a stake and a status in the constitutional order. The Charter developed roots in a remarkably short period of time." 24 The "rights bearers," especially women, aboriginal peoples, and ethnic groups, are proud of their new status but also insecure about their future position. They see their existing rights as achieved only after intense political struggles in the early 1980s. They are watchful for governmental actions that might reduce their status either absolutely or relative to other constitutionally recognized interests. Members of "the citizens' constitution," far from being deferential to political elites, often challenge governments' control over the process and substance of constitutional change. In Cairns' view, the deep tensions between these two perspectives on Canadian constitutionalism evoke a profound question - whose constitution is it?

23.

See, for example, Alan C. Cairns, "Citizens (Outsiders) and Governments (Insiders) in Constitution-Making: The Case of Meech Lake" (1988) XIV Canadian Public Policy at 121-145.

24. 
The literature is replete with references rooted in Cairns' analysis. Roger Gibbins, for example, contrasted the 1982 constitutional settlement with its emphasis on such "peoples' issues" as the Charter and patriation with Meech Lake's preoccupation with the older agenda of governmental powers and Quebec's position within Confederation. ${ }^{25}$ Mary Eberts, in a stinging critique of Meech Lake's possible impact on women's rights, points to the outrage of what she labelled "the equality seeking sector."26 Various authors worried about an emerging "hierarchy" of rights and interest groups complained that their needs had been shunted to the back of the bus. And John Whyte, Dean of Law at Queen's University, portrayed Meech Lake as obsessed with governmental powers and the position of Quebec and as indifferent, indeed in some ways hostile, to emerging issues of gender, social class and multiculturalism. ${ }^{27}$ For many observers, therefore, Meech Lake symbolized yesterday's agenda, one that was increasingly anachronistic in modern Canada.

The impact of the "Distinct Society" clause on the interpretation of the Charter was the principal battleground between the conflicting viewpoints of the citizens' constitution and the competing governmental agenda. The debate was decidedly complex and one, despite its deep political implications, that was dominated by legal analysis. It is doubtful that many Canadians ever fully understood the essence of the argument as it was conducted for three years as a debate between lawyers.

Defenders of the Meech Lake Accord argued that the Distinct Society provisions neither conferred new substantive powers on the government of Quebec nor challenged extant Charter rights. The provision was to have operated as an interpretative clause, a prism through which the courts would have viewed the Charter. Moreover, Meech Lake supporters argued that opponents exaggerated the potential for governmental abuse of the Distinct Society clause. ${ }^{28}$ In their view, it was improbable that a present or future government of Quebec would employ the Distinct Society clause to reduce, for example, women's rights in pursuit of policy objectives related to the protection of Quebec's distinctiveness. Other arguments, not necessarily advanced by supporters, noted that the real threat to equality rights is Section 33 and that Section 1 can be employed to defend governmental actions detrimental to equality rights. ${ }^{29}$ And Donna Greschner, in an insightful theoretical treatment of the legal issues, developed the intriguing argument that Roger Gibbins, "A Sense of Unease: The Meech Lake Accord and Constitution-Making in Canada" in Gibbins, ed., supra, note 4, at 121-130.

26. Mary Eberts, "The Constitution, the Charter and the Distinct Society Clause: Why are Women Being Ignored?" in Behiels, ed., supra, note 2, 302 at 308.

27. John Whyte, "The 1987 Constitutional Accord and Ethnic Accommodation" in Swinton and Rogerson, eds., note 3, at 263-270.

28. See, for example, Peter M. Leslie, "In Defence of the 'Spirit of Meech Lake': Evaluating the Criticisms" in Behiels, eds., supra, note 2, 483 at 494.

29. Katherine Swinton, "Competing Visions of Constitutionalism: Of Federalism and Rights" in Swinton and Rogerson, eds., supra, note 3, at 279-94.
} 
the Charter's various interpretation clauses are subordinate to its substantive clauses. ${ }^{30}$ While concerned about the confusion engendered by Meech Lake, she believed that critics exaggerated its threat to equality rights.

Critics of the Accord, especially, but by no means exclusively, spokespersons for anglophone women's groups, were little moved by such claims. They maintain that Meech Lake's supporters could not prove that the Distinct Society provisions would not have been employed to justify measures destructive of equality rights. They are outraged, moreover, by governments' refusal to amend the Accord so as to put the matter to rest. For if, as the supporters maintain, Meech Lake's provisions do not challenge equality rights, why can it not be said in the text? Section 16 of the Accord further worried and angered women's groups and other interests. Here the concern was the creation of a constitutionally sanctioned "hierarchy" of rights. Why were the aboriginal and multicultural provisions of the Charter and the Constitution Act explicitly removed from the sway of the Distinct Society clause while equality rights are ignored? Was silence about equality rights evidence that governments anticipated a challenge to them from the Distinct Society provisions? As Mary Eberts put it: ${ }^{31}$

The govermment's argument that section 2 adds no new threat to existing rights breaks down in the face of section 16 of the Accord. That clause explicitly provides that nothing in section 2 "affects" aboriginal and multicultural provisions of the Charter and Constitution Act. Obviously, it was contemplated by the Meech Lake framers that section 2 would have some effect beyond constitutional business as usual or they would not have included this clause. There has never been a satisfactory explanation for protecting aboriginal and multicultural provisions from the reach of section 2 , but not protecting equality rights.

The debate about the interplay between the Distinct Society provisions and the Charter reveals the complexity that Meech Lake would have injected into judicial review. The Charter would have contained several potentially conflicting interpretation clauses through which substantive rights had to be examined. But more profoundly, the debate attests to the accuracy of Cairns' arguments about the emergence of the "citizens' constitution." Newly mobilized constitutional actors objected deeply to Meech Lake's provisions, not simply because the Accord represented a vision with which they disagreed, but also because they saw its terms as directly threatening to their constitutional status. Herein lies a cardinal reason for the substantial opposition the Accord faced in many quarters. In the final analysis, the demands of the "citizens" constitution and the governmental agenda were irreconcilable. Rights" in Swinton and Rogerson, eds., supra, note 3, at 55-64.

31. Mary Eberts, "The Constitution, the Charter and the Distinct Society Clause" in Behiels, ed., supra, note 2, 302 at 314. 
In her analysis of the implications of the Distinct Society clause for womens' rights, Lynn Smith asked several compelling questions. ${ }^{32}$ Foremost among these was a concern about why the public purposes served by the Distinct Society clause were assumed to be more important than the full protection of liberties and rights. Far too little attention has been paid to this fundamental question, the debate having been sidetracked by secondary concerns about the implications of the Distinct Society clause for judicial review. A brutally frank answer to Smith's question was provided by Jose Woehrling, a defender of the Accord, who boldly asserted that national unity is self-evidently more important than the achievement of social justice for Meech Lake's critics. As he put it: ${ }^{33}$

The idea was not to create an official "family portrait" of Canadian society with each group occupying its rightful constitutional place, but rather to resolve the difficulties created by Quebec's non-adherence to the Constitution Act, 1982. This problem is of paramount importance, for at stake is the unity of Canada. It thus takes priority over the problems of social justice raised by the opposing groups.

A related, although less frankly stated view, is advanced by Meech Lake supporters who argued that the Accord had to be passed so as to rid the constitutional agenda of the "Quebec question" thereby making space for deeper discussion of the citizens' constitution. ${ }^{34}$ This claim is merely a gentle reassertion of the primacy of national unity over competing political values. Interestingly, the failure of Meech Lake revealed that many interests were neither trusting nor patient enough to have their concerns dealt with in a "second round" of negotiations.

What is distressing about these arguments is the utter casualness with which Meech Lake supporters assert the paramount importance of national unity. No philosophical arguments were advanced in support of their pronouncements--the case for the preservation of the Canadian state was taken as self evident. What view of democratic society underpins the notion that a state's territorial integrity is a higher value than the rights of citizens and groups within the state? Under what circumstances, if any, would questions about rights and policy effectiveness prevail over unity concerns? What view of politics or the distribution of political power sustains the case, for example, that aboriginal rights ought to receive greater recognition than those of women? Recent Canadian constitutional discourse is distressingly silent on such questions.

Governments' silence on the philosophical bases of constitutional change is understandable, albeit lamentable. But the indifference of Canadian scholars is a more disturbing and complex matter. An explanation for the narrow scholarly interpretations of constitutional change and the presumed importance of national unity stresses the

32 Lynn Smith, "The Distinct Society Clause in the Meech Lake Accord: Could it Affect Equality Rights for Women?" in Swinton and Rogerson, eds., supra, note 3, at 35-54.

33. Jose Woehrling, "A Critique of the Distinct Society's Clause Critics" in Behiels, ed., note 2, 171 at 198.

34. See, for example, Richard Simeon, "Meech Lake and Visions of Canada" in Swinton and Rogerson, eds., supra, note 3, 295 at 304. 
stranglehold wielded by students of federalism and constitutional law. Their perspectives stress such questions as the division of powers and the political salience of territorial cleavages. The result is a narrow, aphilosophical discourse.

Are we well served by such a constitutional debate? One wonders whether governments in seeking popular support for Meech Lake might have been wiser to root their appeals in deeper, franker reasoning. Instead of vague claims about national reconciliation and the overarching political need to bring Quebec into the constitutional fold, governments might have acknowledged the conflicts of interest, vision and aspiration at stake and anchored their appeals in coherent arguments about the importance of national unity relative to competing claims. Meech's supporters should also have fleshed out their implicit claims about the adverse economic, political and social consequences of an independent or more autonomous Quebec. A more direct approach to the Meech Lake Accord, by establishing clearly the stakes and the issues, would not have reduced the resulting political conflict. But, if nothing else, it would have altered the core questions and reduced the bitterness of those critics who saw governments as operating in bad faith. In this context, it is difficult to disagree with Wayne Mackay's appeal for greater governmental honesty in noting the value choices in the Accord and its Distinct Society provisions: $:^{35}$

The "distinct society" clause either means something and will have an impact on constitutional interpretations, or it is a hollow promise which will serve to further alienate Quebec within Confederation. Whatever the real intent and impact of the Accord, the politicians supporting it should take responsibility for the important value choices being made and not merely pass the buck to the courts. Given the positive aspects of the Accord, it may be worth the cost, but the federal government and other supporters of the constitutional change should be honest about the potential costs and who is likely to bear them.

The Meech Lake literature is inexcusably weak in its articulation of criteria for evaluating constitutional change. Supporters of the Accord advance a remarkably narrow and suspect list. One implicit criterion, stressed by most supporters, is that Meech Lake is acceptable because it is rooted in past proposals, practices and debates. ${ }^{36}$ A major constitutional reform is therefore good merely because it embraces in a new package, what has gone before. But what is inherently virtuous about such an agreement? A shallower, and very conservative, proposition asserts that when dealing with Meech Lake we must abandon high standards and ask instead only whether the deed is acceptable given political realities. As Richard Simeon argued in his defence of the Accord. ${ }^{37}$

35. A. Wayne MacKay, "Linguistic Duality and the Distinct Society in Quebec: Declarations of Sociological Fact or Legal Limits on Constitutional Interpretation?" in Swinton and Rogerson, eds., supra, note 3,65 at 78 .

36. See, for example, Richard Simeon, "Meech Lake and Visions of Canada" in Swinton and Rogerson, eds., supra, note 3 at 295-306.

37. Richard Simeon, "Political Pragmatism Takes Precedence Over Democratic Process" in Behiels, ed., supra, note 2, at 125-6. 
I do not really ask whether it is the best we could have done but rather, is it an acceptable, workable compromise or not? The question is not, "Is the process ideal?" but "Does it meet our basic standards, and could we imagine in the real world of politics a much better way we could have done it at this time?"

This argument presumes that major constitutional changes should not be subject to more penetrating analysis or justification than other governmental activities. Put differently, constitutions should be assessed in terms of their ability to resolve current problems and in terms of their acceptability to decision-makers. Such a posture begs such questions as acceptable to whom and under whose definition of political reality.

The dictum that we adopt "realistic" criteria for evaluating major constitutional changes is an example of what Arnold Kaufman, a political philosopher, calls "role playing." ${ }^{.38}$ Kaufman probes the assertion that a responsible citizen, when evaluating political problems, must examine options "realistically" as if he himself were a decision-maker. When citizens examine political change from this vantage point, the articulation of utopian or radical alternatives becomes irresponsible as politics, after all, is the art of the possible. Kaufman argues convincingly, however, that citizens, by engaging in such role playing, minimize their impact on policy and reduce the quality of democratic debate by limiting the range of options assessed. Role players abound in the scholarly literature about Meech Lake.

For what combination of political, philosophical and ideological reasons should Canadians have lowered their sights and accepted a constitutional reordering that was admittedly imperfect? Why, to employ common parlance, should we have held our noses and passed Meech Lake? Moreover, should our criteria for evaluation not include, to cite just a few, such factors as the suitability of the constitution's social vision, the effectiveness of policies that might be justified under its terms and the implications of its language and symbolism? Such questions were ignored in the Meech Lake debate even though they are at the heart of the controversy.

\section{THE PROCESS OF CONSTITUTIONAL REFORM}

The process of constitution-making culminating in the Meech Lake Accord, has been severely criticized. At the heart of many critiques is the view that the process was too dominated by the First Ministers, too devoid of serious public input and participation, and too secretive. Not surprisingly, women's groups, aboriginal peoples' organizations and the territorial governments, all of whom had major disagreements with the substance of the Accord, are among the most severe critics of the process. They remain outraged by their exclusion from an exercise in constitution-making that adversely affects their interests. 
Critics assert that the Meech Lake Accord was sprung on unsuspecting citizens and interest groups. Unlike the process culminating in the Constitution Act of 1982, the public was not deeply or emotionally involved in a prolonged debate. ${ }^{39}$ There was limited prior debate about alternative constitutional visions or structures. Indeed, the process of negotiation culminating in the Meech and Langevin texts was secret and entirely orchestrated by the First Ministers and their bureaucratic entourages. In a remarkably short time, a major constitutional revision was agreed to and presented as a comprehensive package. As Alan Cairns remarked: "The process was beginning to look more like a military manoeuvre by governments to keep the citizens at bay than an acceptable process of constitution-making in one of world's oldest liberal democracies. ${ }^{.40}$

Such problems were compounded by governments' refusal to permit widespread debate after the Accord was struck. Rather arrogantly, governments claimed that the negotiations culminating in the Accord were so complex and delicate that the agreement was unamendable unless "egregious errors" were discovered. But in a gesture toward democracy, Parliament and the provincial legislatures were required to ratify a constitutional Accord that governments saw as an unchangeable, "seamless web." The emergence of a broad, wide-ranging debate was further inhibited when the two major opposition parties in Parliament declared their support for the Accord. ${ }^{41}$ As a result, the federal government's basic rationale for the agreement was not subject to the potentially penetrating assessment that a determined, competitive legislative opposition could muster.

Observers note other serious flaws in the process. For one thing, it is extraordinarily difficult to hold the First Ministers collectively accountable for their deeds once they retire to their home jurisdictions. ${ }^{42}$ The secrecy surrounding the negotiations makes difficult the task of the critic seeking an assessment of the alternatives considered and rejected by governments. As an example of this problem, it remains the subject of speculation how far Mr. Mulroney was prepared to sacrifice federal powers at Meech Lake and Langevin in his pursuit of an agreement.

The tortuous week of negotiations in Ottawa in early June 1990 and the Prime Minister's bizarre defence of the events heightened public concern about the process of Canadian constitution making. The week long spectacle of weary, often angry, First Ministers secretly discussing proposals to which only they were privy fuelled the anger of those who felt excluded and emphasized the distinction between constitutional insiders (the first ministers) and outsiders (everyone else). Such a chaotic process, where fact and rumour quickly become indistinguishable, contributes to an unhealthy proliferation of worst case scenarios and conspiracy theories which do little to advance public understanding or trust.

39.

Roger Gibbins, "A Sense of Unease: The Meech Lake Accord and Constitution-Making in Canada" in Gibbins, ed., supra, note 4, at 121-130.

40. Alan C. Caims, "Ottawa, The Provinces and Meech Lake" in Gibbins, ed., supra, note 4, 105 at 108.

41. See, for example, William F. Gold, "Meech Mumbles" in Gibbins, ed., supra, note 4, at 147-149.

42. Alan C. Caims, "Ottawa, The Provinces and Meech Lake" in Gibbins, ed., supra, note 4, 105 at 106. 
Meech Lake's supporters mounted a defence, albeit an unconvincing one, of the procedures employed. They claim, among other things, that there was adequate prior debate about the proposed changes. Viewed in this way, the Meech Lake process meets their standards of democratic legitimacy. For example, supporters claim that the thrust of Mr. Mulroney's position was outlined as early as the 1984 election campaign and that Quebec's five proposals were common knowledge for a year prior to the negotiations. ${ }^{43}$ The former argument deserves high marks for its cleverness if not its realism while the latter argument reflects the perspectives of constitutional experts who are familiar with the intricacies of constitutional development and who assume others bring to bear comparable knowledge and insight. A related notion - that the Meech Lake proposals merely packaged a series of well known constitutional changes that have been debated intermittently for three decades - further reveals the insiders' bias and viewpoint. But while insiders were aware of the impending Accord, most Canadian citizens cannot readily make the same claim. Media coverage of the Accord during even its most public moments was superficial and very oriented to personality and regional issues, little sustained public debate occurred prior to the governmental negotiations and few competing definitions of the problem emerged. ${ }^{44}$

Meech's supporters viewed its provisions for mandatory legislative approval as a major improvement in the democratic process. When confronted with arguments questioning the value of legislative debate that cannot produce change, supporters assert that governmental control of legislatures is the norm and that Meech Lake's approval process is congruent with established practice. ${ }^{45}$ These arguments imply that normal Parliamentary procedures are suitable for vetting major constitutional changes. Perhaps they are, although the critics disagree profoundly, but no clear rationale is advanced. Is there some compelling reason to eschew greater public input or experimentation with new forms of citizen participation? Nor do supporters of the Meech Lake process deal with the vexing problem of substantial interjurisdictional variations in the procedures employed. For example, Ontario held important public hearings on the Accord while the government of Alberta refused to do so. A cardinal virtue of federalism is its alleged capacity to permit provincial variation in the disposition of policy problems. But is the process of constitutional approval an area where provincial distinctiveness should prevail?

A final argument about the process defers to the critics and admits that the process is flawed but further asserts that the Accord's overriding political purposes must prevail over objections about democratic procedure. This argument poses few problems for either

43. Richard Simeon, "Political Pragmatism Takes Precedence over Democratic Process" in Behiels, ed., supra, note 2,125 at 128.

4. For useful analyses of mass media coverage of the Meech Lake negotiations and debate see David Taras, "Meech Lake and Television News" in Gibbins, ed., supra, note 4, at 219-34 and Lorry Felske, "Fractured Mirror: The Importance of Region and Personalities in English Language Newspaper Coverage of Meech Lake" in Gibbins, ed., supra, note 4, at 247-60.

45. See, for example, Richard Simeon, "Political Pragmatism Takes Precedence over Democratic Process" in Behiels, ed., supra note 2, 125 at 129. 
ardent supporters of the Accord or for those who oppose it on both substantive and procedural grounds. It raises dilemmas, however, for the probably sizeable group of Canadians whose primary objections to the Accord concern its democratic aspects. How important are procedural concerns when weighed against arguments about the content of constitutional documents? Were worries about the adequacy of the process sufficient grounds for rejecting the Accord? The debate and literature about Meech Lake paid little attention to such complex questions.

The various concerns about the quality of Meech Lake's democratic process highlight the need for more creative thought about how to reform the constitution-making process. While critics abound, few comprehensive alternative blueprints have been drafted. Various proposals merit careful scrutiny. These range from broadly based constitutional conventions and the wider use of referenda to reforms that are closer to the status quo. In this vein, the enthusiastic proponents of procedural change are reminded that the Meech Lake debate was characterized by deep conflicts of interest and that changes to the process, while possibly restructuring the agenda, will not by themselves resolve deep seated grievances.

The process culminating in the failed Meech Lake Accord is commonly described as an insult to Canadian democracy. While there is a basic truth to such an assertion, the Meech Lake outcome can also be interpreted as a victory for democracy. Changed political circumstances in Manitoba, New Brunswick and Newfoundland complicated significantly the process, raised new matters for debate and called the undertaking into question. The relentless critiques of womens' groups, aboriginal peoples, advocates of a "Triple E" Senate, and the territorial governments, to cite just a few, have added a long list of new items and reform proposals to the constitutional agenda. In the face of such pressure, a Parliamentary committee was struck in early 1990 to investigate the need for further change to the Accord in light of Premier McKenna's proposals. The three year ratification period, a very long time given the haste with which the Accord was constructed, provided opposing groups and newly elected governments with ample time to mobilize.

The normal political pressures of a democratic society altered the process and determined the outcome. In the face of widespread public opposition, governments were unable to limit the debate on terms acceptable to them, to control the ratification process and to appease critics by promises of future consideration of their grievances. While the process left much to be desired, Meech Lake's critics may take some consolation in the observation that politics mattered.

In reflecting on the Meech Lake debates, one wonders whether the various critiques of the process are limited to the peculiar circumstances of the constitutional debates or whether they reflect the deeper malaise of an alienated citizenry. Is there a growing dissatisfaction with indirect democracy as it operates in Canada? Are citizens tiring of their role as objects of political manipulation? Do attitudes on such questions differ regionally, by gender or by social class? The Meech Lake literature does not probe such 
questions but they underpin the arguments about the process and are hence worthy of serious examination.

\section{THE POLITICS OF CONSTITUTIONAL REFORM}

The underlying politics of Meech Lake have not been subject to much penetrating analysis. Most observers stress how the broad contours of the agreement resulted from the near simultaneous election of a Prime Minister bent on "national reconciliation" with the election in Quebec of a federalist Liberal government after eight years of Parti Quebecois rule. Other commonly noted features of the political landscape include the support of the federal Liberals and New Democrats for the Accord with resulting internal divisions within each party. The support of the other provincial governments is generally attributed to the irresistible lure of greater powers for them as offered by a conciliatory prime minister committed to a constitutional settlement with Quebec.

Such generalizations have merit, but our understanding of the political dynamics of Meech Lake is woefully incomplete. Despite the impression that constitutional matters have preoccupied Canadian scholars, substantial gaps remain in our knowledge. For one thing, extraordinarily little attention has been paid to the internal politics of Canada's provinces as they relate to constitutional affairs. Howard Palmer and Gerald Friesen have provided useful preliminary accounts of events in Alberta and Manitoba respectively. ${ }^{46}$ But we lack systematic investigations of how the confluence of partisan politics, perennial cleavages, political cultures and socioeconomic factors combine to shape, and be shaped by, provincial constitutional positions. No convincing explanations account for the dissenting positions of governments in Manitoba, New Brunswick and Newfoundland.

In analyzing Meech Lake negotiations, precious little attention has been paid to the links between the Accord and the traditional constitutional positions of the provinces. The general assumption is that the provincial governments, other than Quebec, entered the debate without coherent strategies or designs. Their response is thus explained by an apparently inherent lust for power and status. But is this a correct and wide-ranging enough account? One wonders, for example, in light of Alberta's continuing emphasis on the "equality of the provinces" as a basic constitutional principle. ${ }^{47}$ And what of Ontario's apparently limited role in these events? How has the government of Canada's most prosperous and heavily populated province influenced the federal position and those of the other provinces? Has the province ceded its position as a mediator? What are the

Howard Palmer, "The Flaws of the Meech Lake Accord: An Alberta Perspective" in Gibbins, ed., supra note 4 at 37-44 and Gerald Friesen, "Manitoba and the Meech Lake Accord" in Gibbins, ed., supra, note 4 at 51-58.

47. For an elaboration of this point see Donald V. Smiley, "Meech lake and free trade: studies in Canadian federalism" (1989) 32 Canadian Pub. Admin. 470 at 476. 
constitutional consequences of the continuing political standoff between Queen's Park and Ottawa? What are the implications for future constitutional negotiations? ${ }^{48}$

Quebec's complex internal politics are not analyzed extensively in the English Canadian literature on the Meech Lake Accord. Little sustained attention is paid to the province's changing economic structure, to its demography, to its class structure, to its various strands of nationalism or to the constitutional views of non-governmental actors. As a result, Quebec's constitutional agenda is not related to broader patterns of political and economic development and the constraints on the provincial government's bargaining strategies are little appreciated. By failing to convey the complexity of modern Quebec, the literature sustains simplistic English Canadian interpretations of Quebec's constitutional position and the resulting negotiations. Far too much attention is paid to the constitutional superstructure while far too little attention is paid to its political foundations.

The Meech Lake debate and the related scholarly literature stress how constitutional discourse is shaped by competing visions. But while visions are important, much less is said about the position and strength of conflicting interests and the power relations involved. To be sure, Alan Cairns' interpretation stresses the emergence of new constitutional actors, issues and outcomes. But his focus is the advent of a constitutionally determined hierarchy of interests rather than the class basis of constitutional reform. Class relations, as either determinants or products of constitutional change, are ignored. Indeed, in the four volumes examined, not a single essay analyzes the Meech Lake Accord from a class perspective. The dominant image presented of Canada is that of a classless society preoccupied by traditional linguistic, ethnic and territorial cleavages.

Some observers link the free trade agreement and the Meech Lake Accord with a view to showing how both reflect a capacity to reduce significantly the interventionist appetites of governments. ${ }^{49}$ But no political economy interpretations of constitutional change have emerged. ${ }^{\text {so }}$ The Canadian left has produced no coherent vision of constitutional events having abandoned the field to orthodox political science and constitutional law. The left's virtual withdrawal from constitutional discussions robs the subsequent debate of a different perspective, a complex agenda and a powerful political dynamic. In the absence of competing ideological interpretations, the resulting debate is more easily monopolized by the narrow agenda of federal questions and governmental concerns. Legitimate views

48.

For a valuable discussion of Ontario's role in modern Canadian federalism see Donald W. Stevenson, "Ontario and Confederation: A Reassessment" in Ronald L. Watts and Douglas M. Brown, eds., Canada: The State of the Federation 1989 (Kingston, Ontario: Institute for Intergovernmental Relations, 1989) at 53-74.

49. See, for example, Raymond Breton, "The Concepts of 'Distinct Society and Identity' in the Meech Lake Accord" in Swinton and Rogerson, eds., supra, note 3 at 3-10.

so. For a useful effort to provide an altemative perspective on the political role of the Charter of Rights and Freedoms see Michael Mandel, The Charter of Rights and the Legalization of Politics in Canada (Toronto: Wall and Thompson, 1989). 
about the proper economic and social roles of governments and the interests served by elites through constitutional change are difficult to articulate.

An obvious retort to this argument is to assert that the Canadian left, particularly its dominant social democratic strand, advances an extraordinarily moderate and orthodox view of politics which says little about class relations in constitutional or other matters. While true to a degree, the Canadian left has traditionally argued that a strong federal government is the locus of social progress and a bulwark against the excesses of often reactionary provincial governments. Whether correct or not (the left's traditional argument has recently been severely challenged by social democrats from western Canada), this perennial argument formed the basis of a distinctive view of the political economy of federalism and constitutional renewal. But given the support of the federal New Democrats for Meech Lake's "provincializing" initiatives, the task of articulating a coherent defence of the national government fell to Pierre Trudeau, his Liberal comrades and an uneasy coalition of Meech Lake opponents. Trudeau's defence of Ottawa is rooted in a very different set of values and premises than the traditional social democratic perspective.

The left's general avoidance of the constitutional debate and its quiet acquiescence in Meech Lake's controversial constitutional vision are difficult to understand. To the extent that the process is seen to be inherently conservative, the left's abstinence almost guarantees that it will remain so. A related possibility, that the left sees the substantive agenda of constitutional change as irrelevant, loses credibility in light of Meech Lake's provisions concerning immigration policy and the spending power. Few policy areas rival immigration in terms of their potential impact on class relations, race relations and industrial policy.

In a similar vein, it is commonplace to remark that Meech Lake was a "power play". But social scientists have not employed Canada's constitutional experiences as vehicles for better understanding where power ultimately lies in this country. The constitutional views of business and labour, for example, are seldom examined systematically. Neither the critiques of the democratic process nor the Distinct Society/Charter debates have been integrated with deeper reasoning about the exercise of power in this country. In examining constitutional discourse, we have avoided both the underlying philosophical issues and the power politics involved.

As noted several times in this review, the bulk of scholarly literature on Meech Lake is written by constitutional experts and students of federalism. The result is a literature that dissects the issues into discrete components, stresses issues about governmental power and fails to generate competing general interpretations. As well, scholarly analysis of Meech Lake has generally followed the broader political debate. That is, scholars have debated the same issues as governments without trying to reorder the discourse or to cast it in different analytical perspectives. Few investigators have employed recent constitutional debates as springboards for launching investigations into other important concerns or to generate broader lessons about the nature of Canadian politics. The 
experience of other countries is seldom systematically explored as a basis for understanding the dynamics of the Meech Lake negotiations.

Scholars who are not regular contributors to the constitutional literature have made interesting contributions, have expanded the research agenda, and have posed important questions for future constitutional debates. For example, David Taras, an expert in political communications, shows masterfully how modern television as a communications medium has enormous problems covering complex political events like the Meech Lake Accord. $^{\text {s1 }}$ Employing communications theory, he examines how modern television, by its very character, forces political events into a mould that stresses personality, snapshot coverage, and process rather than content. Taras uses Meech Lake as a vehicle for understanding the political role of the mass media in a way that enhances our comprehension of his topic and the Meech Lake debate. His investigation helps explain the curious situation where many Canadians apparently held strong views about the Accord while admitting that they did not understand its content or implications. Taras' analysis also demonstrates why media coverage of Meech Lake ultimately failed to offset the deep deficiencies of the democratic processes employed. In a different vein, Andre Blais and Richard Johnston employ public opinion surveys and the insights of political sociology and psychology to plumb the underlying bases of "mass politics." 52 Among other things, they examine public opinion in Quebec about the importance of various rights with a view to determining whether public attitudes will constrain Quebec governments from using the Distinct Society provisions to infringe on Charter-guaranteed rights. Their work raises several important questions including the role of public opinion surveys in shaping attitudes about constitutional questions. They also remind us forcefully that the results of public opinion surveys are seldom clearcut and are therefore subject to multiple, often conflicting interpretations. Moreover, the analysis of public attitudes, to be meaningful, must be cast in a comprehensive explanatory framework. In this vein, no sophisticated explanation has been advanced to account for English Canada's distaste for Meech Lake. Such concerns are important as the post-Meech Lake debate will undoubtedly be characterized by the publication and discussion of many polls about Canada's future. Another creative insight is provided by Edward Chamberlain, a specialist in comparative literature, who uses his discipline to probe the political significance of Meech Lake's vocabulary. ${ }^{53}$

Such unfortunately infrequent contributions are refreshing. For, unlike the mainstream contributions, they provide new insights and perspectives into a decidedly complex political issue. The "outsiders'" (those who do not regularly contribute to constitutional debates) contributions define the problem in ways different from governments, the media, and the regular academic debaters. They abandon the conventional agenda, ask different

David Taras, "Meech Lake and Television News" in Gibbins, ed., supra, note 4 at 219-34.

R. Johnston and A. Blais, "Meech Lake and Mass Politics: The 'Distinct Society' Clause" (1988) XIV Canadian Public Policy at 25-42.

J. Edward Chamberlain, "Aboriginal Rights and the Meech Lake Accord" in Swinton and Rogerson, eds., supra, note 3 at $11-20$. 
questions and present different perspectives. Second, the "outsiders" seem little concerned about the immediate relevance of their contributions or their short term impact on the broader debate. Their participation in the constitutional arena is more an extension of their research agendas than an effort to sway the course of political events.

\section{CONCLUSIONS}

The literature under review and the collapse of the Meech Lake Accord generate several inescapable, albeit distressing, conclusions. First, the Meech Lake negotiations, far from clarifying and simplifying our constitutional agenda, have expanded and confused it. Second, instead of happily generating a constitutional agreement with Quebec, the debate and the Accord's failure unleashed a range of passions, heightened old antagonisms and created several new ones. The agreement was variously denounced as destroying the federal government's capacity to act on behalf of Canadians, a further testimony to Quebec's disproportionate power, an insult to women, aboriginal people and residents of the territories and, in its negotiation and ratification, an affront to democratic principles. Many Canadians expressed abiding concerns about Meech Lake's impact on their Charter rights and, as a result, were little moved by urgently expressed appeals for compromise in the interest of national unity. Meanwhile, the range of reactions against the Accord generally and the Distinct Society provisions in particular are interpreted in Quebec as a rejection of that province's most moderate constitutional agenda. Disappointed Meech Lake supporters lament the Accord's demise and worry that Canada squandered an historic opportunity to bring Quebec into the constitutional circle. In the supporter's eyes, Meech Lake was a modest set of proposals which, if accepted, would have wed moderate Quebec nationalism with contemporary federal structures. The intensity of the three year Meech Lake debate radically undercut the Accord's potential as a vehicle for national reconciliation.

In light of Meech Lake's failure, Canadians and their leaders may have to debate seriously a range of alternatives to the status quo including variations of the sovereignty association model and little discussed visions of a much looser federalism. Such discussions are already commonplace within Quebec. A "Canada without Quebec," while by no means a certainty, is now a possibility. One can envision few areas of political discourse that we are less able to examine seriously, dispassionately and armed with a reasonable body of serious research. ${ }^{54}$

Another scenario sees future constitutional development as moving in the same direction but much more subtly. The medium term may well witness an incremental, but steady, strengthening of Quebec's "special status" within Confederation. As noted earlier, such a state of affairs may be achieved primarily through bilateral, Quebec-Ottawa, agreements rather than by formal multilateral constitutional negotiations à la Meech Lake.

54. For a fuller elaboration see Alan C. Caims, "Ritual, Taboo and Bias in Constitutional Controversies in Canada" supra, note 1. 
Whether the other provinces will seek or receive comparable status remains unclear. But, rather ironically, the upshot of this scenario is that Quebec might achieve piecemeal a form of sovereignty association within Canadian federalism.

Implicit in the post-Meech discussion is the proposition that Canada now faces major political dilemmas which confound the constitutional quandary. The thrust of the argument is that the Mulroney Tories are exhausted, increasingly unpopular in English Canada and without a strategy for future constitutional changes. On the other hand, the Liberals under Jean Chrétien are said to be out of touch with contemporary debates in Quebec, at loggerheads with the provincial Liberals and unlikely to garner greater support in western Canada. The problem is therefore one of a national party system that, as presently constituted, is unlikely to produce a reasonable constitutional settlement. In Quebec, Mr. Bourassa is firmly in control. He made no serious errors in the protracted Meech Lake debates and knows how to produce enough "gains" under federalism to disarm the Péquistes and the more strident nationalists. Under these circumstances, the Quebec government, not Ottawa or the other provinces, will set the future constitutional agenda. In this scenario, such questions as Senate reform, aboriginal rights and improved procedures for constitution-making are unlikely to figure prominently.

Such complex developments and debates will push Canadian scholars to their limits. As a starting point, we must reflect carefully about the lessons learned over the last few years both about constitutional developments and the role of scholars in major national controversies. Future debates must fully embrace, moreover, the contributions of political philosophers, economists and students of public policy. They cannot be captured by default by experts on constitutional law and federalism. We must advance clear criteria for evaluating constitutional change, distill the basic philosophical questions, propose alternatives to the present process and generate holistic interpretations. More controversially, academic observers must do a better job articulating alternative social visions as antidotes to the political orthodoxies espoused by governments and the media. 